\title{
MODEL PENDIDIKAN KARAKTER ANAK USIA DINI DAN ANAK USIA SEKOLAH DASAR DI JEPANG.
}

\author{
Budi Mulyadi \\ Program Studi Bahasa dan Kebudayaan Jepang, Fakultas Ilmu Budaya, \\ Universitas Diponegoro
}

budi.mulyadi09@gmail.com

\begin{abstract}
Abstrak
Penelitian ini berjudul model pendidikan karakter anak usia dini dan anak usia sekolah dasar di Jepang. Tujuan utama penelitian ini untuk mengetahui bagaimana penerapan pendidikan karakter anak usia dini dan anak sekolah dasar di Jepang. Penelitian ini merupakan jenis penelitian kombinasi antara penelitian studi pustaka dengan penelitian lapangan. Langkah metode yang digunakan dalam penelitian ini adalah meliputi observasi, wawancara, klasifikasi, analisa, interpretasi sintesa dan deskripsi. Dari hasil penelitian secara garis besar dapat digambarkan bahwa terdapat keunikan dan perbedaan dari penerapan pendidikan karakter di jenjang anak usia dini dan anak sekolah dasar. Namun ada persamaan dalam penerapan pendidikan karakter yaitu baik pendidikan karakter anak usia dini maupun anak sekolah dasar sangat mementingkan pendidikan moral dan kepribadian. Pendidikan moral dan kepribadian tidak diajarkan melalui mata pelajaran khusus tetapi diterapkan dalam kehidupan sehari-hari.
\end{abstract}

Kata kunci : Anak Usia Dini; Anak Sekolah Dasar;, Jepang; Pendidikan Karakter

\begin{abstract}
The title of this paper is The character education of early childhood and elementery school age children in Japan. The main goal of this research is to know how to apply the character education of early childhood and elementery school age children in Japan. This research is the combination between liblary reaserach and field research. The step method used in this research is observation, interview, clasification, analysis, interpretasion and description. From the result of this paper in general can be describe there are uniqueness and differences from the application of character education of early childhood and elementery school age children in Japan. But there are similarities that both are very concerned with moral education and personality. Moral education and personality is not taught trough special subject but is applied in daily life.
\end{abstract}

Keywords: character education early childhood; elementary school children; Japan;character education

\section{PENDAHULUAN}

Jepang adalah salah satu negara di dunia yang terkenal unggul dalam hal karakter sumber daya manusianya. Beberapa karakter unggul yang diketahui dunia yang dimiliki bangsa Jepang diantaranya suka bekerja keras, disiplin, jujur, inovatif. Karakter-karakter unggul ini dimiliki orang Jepang tidak lepas dari keberhasilan mereka dalam menerapkan pendidikan karakter dimulai dari usia anakanak. Bangsa Jepang menyadari pentingnya pendidikan karakter dimulai dari usia anak-anak karena mendidik karakter pada anak-anak akan lebih mudah dilakukan daripada mendidik karakter usia 
remaja atau dewasa. Anak anak diumpamakan seperti kertas kosong yang belum terisi apa-apa sehingga pendidikan karakter yang baik yang diajarkan pada anak-anak akan mudah tertanam dalam fikiran mereka dan membekas sampai usia dewasa. Keberhasilan dalam membangun karakter unggul juga dipengaruhi oleh kebijakan pemerintah dalam bidang pendidikan. Pendidikan di Jepang bertujuan untuk mengembangkan kepribadian secara penuh dengan berupaya keras membangun manusia yang sehat pikiran dan badan, mencintai kebenaran dan keadilan, menghormati individu, menghargai kerja, serta memiliki rasa tanggung jawab yang dalam dan semangat kemandirian sebagai pembangun negara dan masyarakat yang damai.

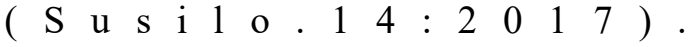

Untuk mencapai tujuan tersebut pemerintah Jepang sangat memperhatikan pendidikan karakter mulai anak usia dini dan anak sekolah dasar karena keberhasilan penerapan pendidikan karakter pada anak usia dini dan anak $\mathrm{s}$ ekolah dasar akan menjadi fondasi pemebentukan karakter yang diharapkan yang disesuaikan dengan tujuan pendidikan di Jepang secara umum seperti yang telah dijelaskan di atas. Bila negara Indonesia mencanangkan penerapan pendidikan karakter untuk seluruh jenjang pendidikan Indonesia mulai tingkat pendidikan anak usia dini sampai perguruan tinggi dimulai pada tahun 2010, negara Jepang sudah lama melaksanakan program pendidikan karakter. Dikatakan bahwa sejak tahun 1970 negara Jepang mulai mengembangkan kurikulum yang berbasis karakter yang mulai ditanamkan dari taman kanak-kanak dan sekolah dasar. Bangsa Jepang berpendapat pendidikan usia dini dan anak sekolah dasar adalah masa emas untuk menanamkan karakter. Selain ini pendidikan karakter usia dini dan sekolah dasar tidak hanya dilakukan di lembaga formal saja tetapi pendidikan karakter dimulai dari keluarga. Keluarga dan sekolah bekerja sama membentuk karakter anak usia dini sehingga menghasilkan fondasi unggul sumber daya manusia. Negara Jepang menyadari bahwa bila ingin berhasil dalam pembangunan, yang harus pertama kali dibangun adalah karakter sumber daya manusianya. Hal ini bisa dibuktikan Jepang menjadi negara maju dalam berbagai bidang kehidupan padahal dilihat dari kekayaan sumber alamnya Jepang tidak sekaya Indonesia.

Jepang tidak menghasilkan minyak bumi, gas, barang tambang tetapi mereka berhasil membangun bangsanya menjadi bangsa yang unggul dan mengalahkan bangsa-bangsa lain termasuk bangsa bangsa di Eropa. Hal ini dikarenakan mereka mempunyai sumber daya manusia yang unggul dan mempunyai karakter kuat sebagai hasil pendidikan karakter yang dimulai dari usia dini.

Dalam hal pendidikan karakter anak, Jepang mempunyai keunikan tersendiri yang tidak akan ditemui di negara lain termasik di Indonesia. Di lembaga formal seperti TK dan sekolah dasar pendidikan karakter di Jepang difokuskan kepada pendidikan moral dan kepribadian yang tidak diajarkan melalui mata pelajaran khusus tetapi langsung dipraktikkan dalam kehidupan sehari-hari. Ini berbeda dengan di Indonesia, untuk penddikan moral dengan tujuan menciptakan karakater anak yang mengerti moral diajarkan secara resmi dalam mata pelajaran tertentu seperti mata pelajaran $\mathrm{PkN}$ atau mata pelajaran agama. Dalam mata pelajaran tersebut murid diajarkan teori tentang moral dan dibrerikan contoh nyata tentang nilai-nilai moral tersebut. Hal ini berbeda dengan sistem pengajaran moral di Jepang.

Kurikulum Jepang tidak mengkhususkan ajaran moral dalam suatu mata pelajaran. Tidak ada alat ukur untuk mengukur kompetensi siswa tentang hal terebut. Pendidikan moral disampaikan dalam bentuk kurikulum tersembunyi. Bimbingan soal perilaku sosial yang baik disampaikan oleh wali kelas dalam bentuk diskusi atau pengarahan khusus. Meskipun 
tidak dijadikan sebagai mata pelajaran khusus, pendidikan moral yang merupakan bagian dari pendidikan karakter sangat menonjol.

Anak-anak di Jepang belajar tata cara dan berperilaku dengan sesama, orang yang lebih tua, yang lebih muda, yang tidak dikenal serta tata krama lainnya. Mereka juga belajar tentang aturan di sekolah, keluarga dan tempat umum.

Adapun di lembaga non formal keluarga mempunyai peranan penting dalam mendidik karakter anak. Anggapan umum menyatakan bahwa keluarga merupakan pendidik moral yang utama bagi anak-anak. Orang tua adalah guru moral pertama anak-anak, pemberi pengaruh yang paling dapat bertahan lama. Anak-anak berganti guru setiap tahunnya, tetapi mereka memiliki satu orang tua sepanjang masa pertumbuhan. Hubungan orang tua anak juga mengandung signifikansi emosional khusus yang bisa menyebabkan anak-anak merasa dicintai dan berharga atau sebaliknya merasa tidak dicintai dan tidak berharga ( Lickona, 2008:42). Hal seperti ini diterapkan keluarga di Jepang dalam pendidikan karakter anak mereka.

Di Jepang yang paling berperan dalam pendidikan karakter yang berhubungan dengan ajaran moral dan berbudi pekerti adalah ibu. Sistem pendidikan dan kebudayaan Jepang sepertinya sangat mengandalkan peran perempuan dalam membesarkan, mendidik dan mengajar anak-anak di luar sekolah. Karena itu di Jepang dipegang teguh kebijakan “ryosai kenbo” 良妻賢母 yang artinya " istri yang baik dan ibu yang arif" yang menetapkan posisi perempuan selaku manajer urusan rumah tangga dan perawat anak-anak bangsa. Sejak dulu filosofi ini merupakan pola pikir bangsa Jepang dan menjadi kunci pendidikan dari generasi ke generasi ( Mulyadi, 2014:75).

Banyak keunikan dari sistem pendidikan karakter anak usia dini dan anak sekolah dasar di Jepang yang berbeda dengan sistem pendidikan karakter di Indonesia. Untuk mengetahui lebih jauh tentang pendidian karakter anak usia dini dan anak sekolah dasar di Jepang dilakukan penelitian dengan dua rumusan masalah yaitu Bagaimana cara menerapkan pendidikan karakter bagi anak usia dini di Jepang dan Bagaimana cara menerapkan pendidikan karakter bagi anak sekolah dasar di Jepang

Adapun tujuan dari penelitian ini adalah untuk mendeskripsikan pelaksanaan model pendidikan karakter anak usia dini dan anak sekolah dasar di Jepang.

\section{METODE PENELITIAN}

Penelitian ini merupakan penelitian kombinasi antara penelitian studi pustaka dengan penelitian lapangan. Studi pustaka digunakan untuk membuat analisa terhadap masalah yang dikaji. Disamping itu beberapa buku sekaligus juga merupakan data sekunder sedangkan penelitian lapangan dilaksanakan untuk mendapatkan data primer dari orang Jepang langsung Dalam penelitian lapangan digunakan metode wawancara dan observasi langsung terhadap masyarakat Jepang. Berikut ini beberapa langkah metode yang dipegunakan

1. Observasi: metode ini digunakan untuk mendapatkan gambaran kehidupan orang dan masyarakat Jepang. Gambaran yang diperoleh merupakan bahan /data primer yang akan ditelaah

2. Wawancara: teknik ini dilakukan untuk mendapatkan gambaran yang lebih detail tentang bahan kajian. Wawancara dilakukan terhadap orang-orang Jepang, baik dosen maupun mahasiswa, atau sukarelawan berkebangaan Jepang.

3. Klasifikasi: setelah diperoleh bahan yang cukup dilakukan klasifikasi bahan baik dari segi urgenitas maupun dari segi jenis bahan/data.

4. Analisa: dilakukan analisa dilakukan atas bahan yang sudah 
Kiryoku, Volume 3 No 32019

e-ISSN: 2581-0960 p-ISSN: 2599-0497

Tersedia online di http://ejournal.undip.ac.id/index.php/kiryoku

diperoleh dan diperkuat
bahan/informasi dari buku yang
sudah ada.
5. Interpretasi: metode ini digunakan
dengan melakukan interpretasi
untuk mendapatkan pemahamnan
yang tepat terhadap bahan kajian,
untuk mendapatkan ide-ide dasar
dari bahan kajian, dan gambaran
bagaimana bentuk penerapannya
secara aktual
6. Sintesa: dari hasil kajian beberapa
aspek yang sudah diteliti dan dikaji
dengan menguunakan logika
deduktif diperoleh siatu sintesa.
Sintesa ini merupakan suatu
sebagai kesimpulan yang menjawab
permasalahan yang diajukan
Deskripsi: semua bahan penelitian, kajian
ilmiah, dan ujicoba penerapan , sampai
pada kesimpulan akhir dideskripsikan
dengan mempertahankankan prinsip
koherensi.

\section{PEMBAHASAN}

\subsection{Definisi Pendidikan Karakter}

Pendidikan adalah sebuah proses untuk mengubah jati diri seorang peserta didik untuk lebih maju. Menurut para ahli, ada beberapa pengertian yang mengupas tentang definisi dari pendidikan itu sendiri di antaranya menurut $H$. Horne, pendidikan merupakan proses yang terjadi secara terus menerus (abadi) dari penyesuaian yang lebih tinggi bagi makhluk manusia yang telah berkembang secara fisik dan mental yang bebas dan sadar kepada Tuhan seperti termanifestasi dalam alam sekitar, intelektual, emosional dan kemanusiana dari manusia.(Listyarti,:2012:2)

Adapun karakter dalam Kamus Bahasa Indonesia, karakter diartikan sebagai sifat-sifat kejiwaan, akhlak atau budi pekerti yang membedakan seseorang dari yang lain:tabiat, watak.
Sedangkan menurut Thomas Lickona, pendidikan karakter adalah perihal menjadi sekolah karakter dimana sekolah adalah tempat terbaik untuk menanamkan karakter .

Berdasarkan totalitas psikologis dan sosiokultural pendidikan karakter dapat dikelompokan sebagai berikut:

(1) Olah hati, olah pikir, olah $\mathrm{rasa} / \mathrm{karsa}$ dan olah raga

(2) Beriman dan bertakwa, jujur, amanah, adil, bertanggung jawab, berempati, berani mengambil resiko, pantang menyerah, rela berkorban dan berjiwa patriotik

(3) Ramah, saling menghargai, toleran, peduli, suka menolong, gotong royong, nasionalis, kosmopolit, mengutamakan kepentingan umum, bangga menggunakan bahasa dan produk Indonesia, dinamis, kerja sama, dan beretos kerja.

(4) Bersih dan sehat, disiplin, sportif, tangguh, andal, berdaya tahan, bersahabat, kooperatif, determinatif, kompetitif, ceria, gigih, serdas, kritis, kreatif, inovatif, ingin tahu, berfikir terbuka, produktif, berorientasi IPTEKS dan reflektif. ( Listyarti, 2012:8-9)

\subsection{Karakter Umum Bangsa Jepang}

Murni Ramli dalam bukunya yang berjudul " Menjadi Orang Berkarakter dan Berbudaya Jepang " menjabarkan beberapa karakter umum bangsa Jepang yang telah dikenal dunia. Berikut adalah beberapa karakter bangsa Jepang yang dijelaskan Murni Ramli dalam bukunya..

1. Disiplin

Kedisiplinan ( Kiritsu $=$ 規律 $)$ atau shitsuke (躾) adalah karakter yang paling menonjol dalam masyarakat Jepang. Ada beberapa pemikiran yang menjelaskan alasan mengapa orang Jepang sangat kuat dalam hal 
kedisiplinan. Salah satunya ada yang berpendapat kedisiplinan orang Jepang lahir pada masa Edo. Ada juga yang berpendapat orang Jepang sejak lahir sudah membawa genetic disiplin. Akan tetapi Murni Ramli menjelaskan bahwa kedisiplinan orang Jepang bukanlah penampakan genetic, tetapi lahir dari pembinaan dan pendidikan sejak kecil yang kemudian melahirkan pemahaman, kesadaran dan kepkaan terhadap berbagai permasalahan yang muncul di tengah masyarakat.

2. Menghargai waktu

Tidak ada bangsa di dunia ini yang lebih menghargai waktu daripada bangsa Jepang. Dalam masyarakat Jepang terkenal istilah jikan genshu yang mempunyai arti " ketat waktu ". Waktu sangat berarti bagi masyarakat Jepang. Uttuk masalah ketepatan dan penghargaan terhadap pentingnya waktu bisa dilihat pada system penjadwalan transportasi umum seperti kereta dan bis. Kereta berangkat dan datang sesuai dengan jadwal waktu yang telah ditetapkan bahkan sampai ke hitungan detik. Begitu juga dalam acara apapun seperti rapat dimulai sesuai dengan jadwal waktu yang telah ditetapkan. Tidak ada istilah jam karet seperti di Indonesia.

3. Kerja keras

Karakter lain yang dimiliki bangsa Jepang yang diketahui dunia adalah kerja keras. Kerja keras bangsa Jepang sering disimbolkan dengan ungkapan "ganbarimasu" yang berarti saya akan berusaha keras. Karakter suka bekerja keras ini lah yang menjadikan Jepang menjadi egara maju dalam berbagai bidang kehidupan. Sumber daya alam Jepang tidak begitu melimpah tetapi berkat kerja keras mereka bisa mengatasi kekuranagn sumberdaya alam mereka dengan inovasi teknologi tinggi sehingga dengan teknologi mereka bisa menguasai dunia.

4. Detil dan teliti dalam bekerja Murni Ramli dalam bukunya menjelaskan bahwa selain gemar bekerja keras, orang Jepang juga sangat detil dalam penguraian dan pekerjaan sehingga dalam budaya masyarakat Jepang muncul istilah komakai sagyou yang mempunyai arti detil dalam pekerjaan.Mereka tidak menyukai pekerjaan instant dan sangat menghargai proses yang berlangsung tertib dan sistematis serta kedetilan karya.

\subsection{Pendidikan Anak Usia Dini di}

\section{Jepang}

Secara umum pendidikan anak usia dini di Jepang terbagi menjadi dua yaitu:

1. Youchien.

Dalam bahasa Indonesia youchien bisa diartikan Taman Kanak-Kanak. Lembaga ini berada di bawah kementerian Pendidikan Budaya Olahraga Sains dan Teknologi Jepang ynag disebut dengan Monbukagakusho. Pendidikan Taman Kanak-kanak di Jepang didasari pada tiga hal berikut ini.

1. Anak-anak mendapatkan pengalaman sebanyak mungkin

2. Anak-anak belajar melalui bermain

3. Anak-anak berkembang sesuai sifat dan karakter masingmasing

Tujuan pendidian TK di Jepang adalah membangun kekuatan anak untuk hidup dan memiliki landasan 
hidup yang kuat untuk menapaki langkah selanjutnya di kehidupan mereka. ( Juliandi,Putri, 2014:2)

2. Hoikuen

Hoikuen dalam bahasa Indonesia bisa diartikan Taman Penitipan Anak (TPA) . Lembaga ini di bawah kementerian kesehatan, buruh, dan kesejahteraan ( Kousei Roudoushou)

Tujian TPA di Jepang ada dua yaitu :

1. Tujuan Pendidikan Anak Usia Dini yang sama dengan Tujuan Taman Kanak-Kanak yaitu mencakup 5 aspek

a. Kesehatan fisik dan mental

b. Hubungan sosial

c. Hubungan dengan lingkungan dan masyarakat sekitar

d. Kemampuan bahasa

e. Kemampuan ekpresi seni dan kreatif

2. Tujuan sebagai badan atau lembaga yang membantu orang tua melakukan pengasuhan anak bersama keluarga, masyarakat dan lingkungan sekitar

( Juliandi,Putri, 2014:11-12)

\subsection{Pendidikan Sekolah Dasar di Jepang}

Sama seperti di Indonesia, di Jepang pun setelah anak menempuh pendidikan anak usia dini masuk sekolah dasar selama 6 tahun. Berikut uraian mengenai pendidikan sekolah dasar di Jepang yang penulis ambil dari buku karya Saleha Juliandi dan Juniar Putri dalam bukunya yang berjudul " Pendidikan Anak ala Jepang".

Kebijakan Umum Sekolah Dasar

a. Kurikulum di sekolah harus disusun berdasarkan hukum. Kurikulum harus memenuhi tujuan untuk membentuk manusia yang seimbang dengan mempertimbangkan lingkungan dan sekolah serta karakteristik fisik dan mental serta tahapan perkembangan mereka

b. Setiap sekolah harus memastikan bahwa setiap aktivitas pendidikan mereka mengandung nilai moral, baik dalam mata pelajaran, aktivitas khusus, maupun dalam pelajaran terintegrasi.

c. Pendidikan jasmani dan kesehatan harus ditangani secara cepat dan menyeluruh sehingga murid memahami pentingnya memiliki dan menjaga kesehatan dan kekuatan fisik serta menjaga keseimbangan kesehatan fisik dan mental.

\subsection{Pelaksanaan Pendidikan Karakter}

\section{Anak Usia Dini di Jepang}

Pelaksanaan pendidikan karakter anak usia dini di Jepang diselenggarakan secara moderat disesuaikan dengan perkembangan fisik dan mental anak-anak. Dalam sistem pendidikan Taman KanakKanak dan TPA di Jepang, anak-anak dilatih hidup berani, mandiri, disiplin, bertanggung jawab, bekerja sama dan bersosialisasi .

Untuk melatih karakter berani, orang tua tidak diperkenankan menunggu anaknya di sekolah seperti yang sering terjadi di sekolah TK di Indonesia dimana para orang tua banyak yang menunggu anaknya di luar kelas samapi sekolah selesai. Di Jepang orang tua tidak menemani anaknya di sekolah meskipun baru hari pertama dan anaknya menangis. Guru TK di Jepang akan berusaha semaksimal mungkin agar anak - anak TK senang dan segera beradaptasi dengan lingkungan sekolah. Dengan dilaksanakannya sistem seperti ini anakanak usia dini di Jepang sudah dilatih untuk menjadi seorang yang berani memasuki lingkungan baru, berani berpisah sementara dengan orang tua, 
berani bersosialisasi di tempat baru. Sistem ini juga dilakukan agar anak tidak bersifat manja dan selalu bergantung kepada orang tua.

Untuk membentuk karakter mandiri, di Jepang anak usia 3 tahun ke atas, baik di sekolah taman kanak-kanak maupun di penitipan anak, anak mulai dibiasakan mengeluarkan sendiri seluruh isi tas dan meletakan peralatannya di tempat-tempat yang telah disediakan. Misalnya lap tangan digantungkan di rak jemuran, sikat gigi dan cangkir kumur diletakan di sekitar wastafel, termos minum diletakan di rak termos, buku presensi dikeluarkan dari tas, diisi dan diletakan di meja guru, baju hangat dilepaskan dan digantung di rak baju dan lain-lain. Pada saat makan siang pun anakanak dilatih untuk mandiri. Mereka harus makan sendiri dan kemudian membersihkan meja makannya sendiri. Kegiatan seperti itu semua harus dilakukan sendiri oleh anak-anak TK di Jepang dengan tujuan untuk melatih kemandirian sejak usia dini dan untuk menghilangkan sifat menggantungkan diri kepada guru. Guru- TK di Jepang tidak diperbolehkan untuk memanjakan anak-anak TK dengan cara membantu kegiatan-kegiatan di atas.

Untuk melatih sifat disiplin anakanak TK di Jepang diharuskan bisa membuka sepatu sendiri dan meletakannya dengan rapih di tempat sepatu yang telah disediakan. Anak-anak juga diajarkan untuk menyimpan barang-barang seeprti tas, jaket, tempat makan, payung di tempat yang telah disediakan. Anak-anak juga diajarkan membuang sampah pada tempatnya dan membersihkan kotoran yang terlihat. Hal ini juga dilakukan dengan tujuan menumbuhkan sifat cinta kebersiahan dalam jiwa anak-anak. Melatih kedisplinan pun dilakukan dengan cara mengajarkan etika dalam menggunakan toilet seperti misalnya menggunakan tissue, air, secukupnya, mengguyur air setelah menggunakan toilet, mematikan lampu sebelum meninggalkan toilet, menata kembali sandal toilet. Dari kegiatan kecil seperti ini anak-anak TK di Jepang belajar masalah kedisiplinan yang akan tertanam dalam jiwa mereka sampai usia dewasa.

Untuk melatih karakter bertanggung jawab, dalam kelas guru TK melakukan upaya dengan membagi anak dalam kelompok 5-6 orang. Setiap kelompok diberi tanggung jawab khusus misalnya ada kelompok yang bertanggung jawab menjaga kebersihan kelas, menyajikan makan siang, memelihara hewan piaraan kelas dan lain-lain. Tanggung jawab itu dirotasi setiap minggu atau setiap bulan. Anggota kelompok pun diganti secara berkala. Kegiatan ini secara tidak langsung menumbuhkan sifat tanggung jawab pada diri anak-anak usia dini di Jepang sekaligus menumbuhkan sifat suka bersosialisasi. Ketika anak-anak diberi tanggung jawab untuk melaksanakan tugas, mereka akan senang dan penuh tanggung jawab untuk melaksanakan tugas tersebut. Mereka melakukannya dengan riang gembira dan tidak merasa terbebani. Kegiatan-kegiatan di atas pun melatih anak-anak Jepang untuk bisa bekerja sama dalam kelompok untuk menyelesaikan suatu tugas yang diberikan guru.

Anak-anak TK di Jepang belum diajarkan cara membaca, menulis dan berhitung. Di usia dini anak-anak dibekali agar agar menjadi pribadi yang berani, disiplin, mandiri dan bertanggung jawab. Pelajaran diberikan sambil bermain. Dengan sistem demikian, pendidikan Jepang masuk dalam liga elit bersama negara-negara maju.

\subsection{Pelaksanaan Pendidikan Karakter Anak Sekolah Dasar di Jepang}

Pelaksanaan pendidikan karakter anak sekolah dasar di Jepang salah satunya diimplementasikan dalam pelajaran ilmu moralitas yang dalam bahasa Jepangnya disebut dengan "doutoku" . Secara etimologi Doutoku dibentuk dari dua kata yaitu "dou" yang mempunyai arti "jalan" dan "toku" yang mempunyai arti 
"kebaikan". Doutoku secara harfiah mempunyai arti jalan kebaikan dimana melalui pelajaran ini anak-anak SD di Jepang diharapkan akan selalu berbuat kebaikan sesuai dengan norma peraturan yang berlaku di masyarakat sehingga tercipta keharmonisan dalam kehidupan bermasyarakat.

Pelajaran ini memiliki empat aspek penting yaitu, menghargai diri sendiri (regarding self), Menghargai orang lain (regarding to others), menghargai lingkungan dan keindahan (regarding to nature and sublime, dan menghargai kelompok dan komunitas 9 regarding to group and society). Pendidikan moral di Jepang ini diajarkan melalui semua mata pelajaran. Misalnya melalui pelajaran Ilmu Kehidupan (seikatsu). Anak-anak diajarkan kode etika saat di dalam kereta, seperti dilarang berdiri di dekat pintu masuk karena akan menghalangi orang lewat, dilarang berbincang-bincang keras karena akan menggangu penumpang lainnya, mendahulukan penumpang yang akan turun sebelum memasuki kereta, dan lainlain.

( Juliandi,Putri, 2014:64-65)

Melalui pelajaran "doutoku" anakanak SD dilatih untuk memiliki karakter mandiri dan disiplin. Pendidikan kemandirian dan kedisiplinan tidak diajarkan melalui teori yang tertulis dalam buku pelajaran tetapi langsung diaplikasikan dalam tindakan nyata, misalnya berangkat ke sekolah tidak diantar orang tua, kegiatan membersihkan kelas dan sekolah tidak mengandalkan cleaning service seperti di Indonesia karena memang di sekolah Jepang tidak ada cleaning service, kegiatan makan siang dilayani oleh siswa-siswa yang bertugas secara bergiliran yang dilanjutkan dengan kegiatan sikat gigi bersama.

Dari kelas satu SD, anak-anak Jepang diajarkan tentang keterampilan hidup. Pelajaran ini bertujuan untuk melatih anakanak agar mandiri dan trampil dalam menjalani kehidupannya. Pelajaran ini memiliki empat target, yaitu 1) anak mengenal siapa dirinya, 2) anak mengenal hubungannya dengan dengan orang lain dan masyarakat di sekitarnya, 3) anak mengenal hubungannya dengan alam, 4) anak mempunyai keinginan untuk berpikir dan mengekspresikan diri melalui tulisan dan lisan.Melalui pelajaran ini, anak-anak dikenalkan terhadap lingkungan dan masyarakat terdekatnya. Mereka berkenalan dengan para guru, para staf di sekolah, para volunter sekolah, mengenal tugas-tugas sekolah hingga mengenai lingkungan dan kehidupan masyarakat di luar sekolah. ( Juliandi,Putri, 2014:66).

Untuk melatih karakter kerja sama dan kemandirian, anak-anak SD di Jepang berangkat ke sekolah dengan cara berkelompok berdasarkan kedekatan tempat tinggal mereka. Pembagian kelompok ditentukan oleh setiap rombongan terdiri dari gabungan kelas atas dan rendah. Anak-anak kelas atas akan menjadi pemimpin rombongan, dan biasanya mereka berjalan di depan dan belakang, sementara anak-anak kelas rendah berada di tengah. Mereka berjalan dalam dua barisan, memakai topi kuning sebagai pengenal bahwa mereka adalah anak sekolah karena tidak ada baju seragam untuk anak-anak SD di Jepang. (Ramli, 2018;292).

Pendidikan karakter di Sekolah Dasar di Jepang lebih mengutamakan praktik dalam kehidupan sehari-hari. Hal ini berbeda dengan pendidikan karakter di Indonesia yang lebih mengutamakan teori yang diajarkan di dalam kelas melalui mata pelajaran tertentu. Pendidikan karakter anak SD di Jepang juga diajarkan melalui metode learning by doing seperti makan siang bersama, bekerja sama dengan teman, mengucap salam, aktivitas motorik, dan berani tampil di depan kelas.

\section{PENUTUP}

Pelaksaan pendidikan karakter anak usia dini dan sekolah dasar di Jepang dilakukan dengan perencanaan yang mendalam oleh pemerintah jepang sehingga model 
Kiryoku, Volume 3 No 32019

e-ISSN: 2581-0960 p-ISSN: 2599-0497

Tersedia online di http://ejournal.undip.ac.id/index.php/kiryoku

pendidikan karakter anak usia dini dan sekolah dasAR DI Jepang bisa dijadikan contoh oleh negara lain karena terbukti pendidikan nkarakter negara Jepang tersebut telah berhasil mencetak generasi yang unggul dalam berbagai bidang kehidupan sehingga Jepang bisa menjadi negara maju setara dengan negara Amerika dan negara-negara Eropa.

Pentingnya pendidikan karakter diterapkan sedini mungkin terhadap anakanak usia dini telah difahami oleh Jepang sehingga kebijakan dalam penerapan pendidikan karakter anak usia dini dilakukan dengan sungguh-sungguh dan semaksimal mungkin sehingga Jepang dapat dikatakan sebagai negara yang berhasil dalam penerapan sistem pendidikan karakter yang patut dicontoh oleh negara-negara lain termausk Indonesia.

\section{Daftar Pustaka}

Juliandi, Putri. 2014. Pendidikan Anak Ala Jepang, Jakarta: Gramedia

Listyarti, Retno. 2012. Pendidikan Karakter dalam Metode Aktif, inovatif dan Kreatif. Jakarta: Erlangga.

Lickona, Thomas, 2014. Pendidian Karakter Panduan Lengkap Mendidik Siswa Menjadi Pintar dan Baik .Bandung: Nusa Media.

Maunah,Binti, 2016. Sosiologi Pendidikan. Yogyakarta: Kalimedia

Mulyadi, Budi, 2014. Model Pendidikan Karakter Dalam Masyarakat Jepang. Jurnal Izumi Vol 3 No 1. Hal 69-80. Undip Semarang

Ramli, Murni, 2018. Menjadi Orang berkarakter dan Berbudaya Jepang, Yogyakarta: Manggar Media.
Sapardi Djoko Damono,1978.Sosiologi Sastra:Sebuah Pengantar Ringkas. Jakarta: Pusat Pembinaan dan Pengembangan Bahasa, Departemen Pendidikan dan Kebudayaan.

Suryohadiprojo, Sayidiman, 1987. Belajar Dari Jepang. Jakarta: Universitas Indonesia 